\title{
Article
}

\section{The Analogue as a Critical Project}

\author{
McEwan, Cameron
}

Available at http://clok.uclan.ac.uk/21918/

MCEwan, Cameron ORCID: 0000-0002-0683-1708 (2018) The Analogue as a Critical Project. Journal of Architectural Education, 72 (1). pp. 44-45. ISSN 1046-4883

It is advisable to refer to the publisher's version if you intend to cite from the work. http://dx.doi.org/10.1080/10464883.2018.1410653

For more information about UCLan's research in this area go to http://www.uclan.ac.uk/researchgroups/ and search for < name of research Group>.

For information about Research generally at UCLan please go to http://www.uclan.ac.uk/research/

All outputs in CLoK are protected by Intellectual Property Rights law, including Copyright law. Copyright, IPR and Moral Rights for the works on this site are retained by the individual authors and/or other copyright owners. Terms and conditions for use of this material are defined in the policies page.

\section{CLoK}

Central Lancashire online Knowledge www.clok.uclan.ac.uk

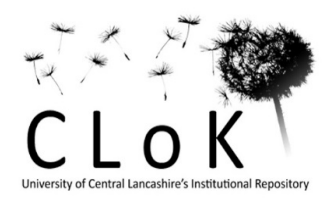




\section{JAE (72:1) Project. Discursive Image}

Cameron McEwan

11 October 2017

\section{Title}

The Analogue as a Critical Project

\section{Image Caption}

Analogical Form. Study for the Analogical City

\section{Image Description}

The drawing is from a suite of 33 drawings that inquire into Aldo Rossi's analogical city, its formal and conceptual principles. In particular this drawing superimposes ten of Rossi's drawings from the IAUS exhibition catalogue entitled Aldo Rossi in America: 1976-1979 (IAUS New York: MIT Press, 1979). Rossi’s drawings are redrawn by the author, together, one after the other and with brevity. Colour and shadow hatching are excluded. The aim is twofold. On one hand the drawing accumulates the material of Rossi's analogical city as an inventory of forms and typical elements, including: geometrical forms, urban types and domestic objects. The combinational and compositional principles that underline the analogical city are figured forth and it is possible to identify the following principles: frame, focus, frontality, horizon, figure, ground, series, and inventory. On the other hand a new project is constructed. The overlaying of multiple drawings simultaneously erases Rossi's project through the mass accumulation of form toward a new representation. A conceptual and formal dialogue is developed with the analogical city. The analogue becomes a critical device toward a methodological and theoretical project. 


\section{Author Bio}

Cameron McEwan teaches architectural design, history and theory at the Grenfell-Baines Institute of Architecture, University of Central Lancashire, and is a Trustee of the AE Foundation, an independent organisation for architecture and education. Cameron studied architecture at Dundee School of Architecture followed by a PhD on the architect Aldo Rossi and the Analogical City at the Geddes Institute for Urban Research, University of Dundee, Scotland. Cameron's work is focused on the relationship between architecture, representation and subjectivity to engage the city as a critical project. Cameron has taught at Dundee School of Architecture, Edinburgh Napier University School of Arts and Wuhan School of Architecture, China. His texts and drawings have been published in Drawing On, Urban Blur, Outsiders for the 2014 Venice Biennale, and elsewhere. 


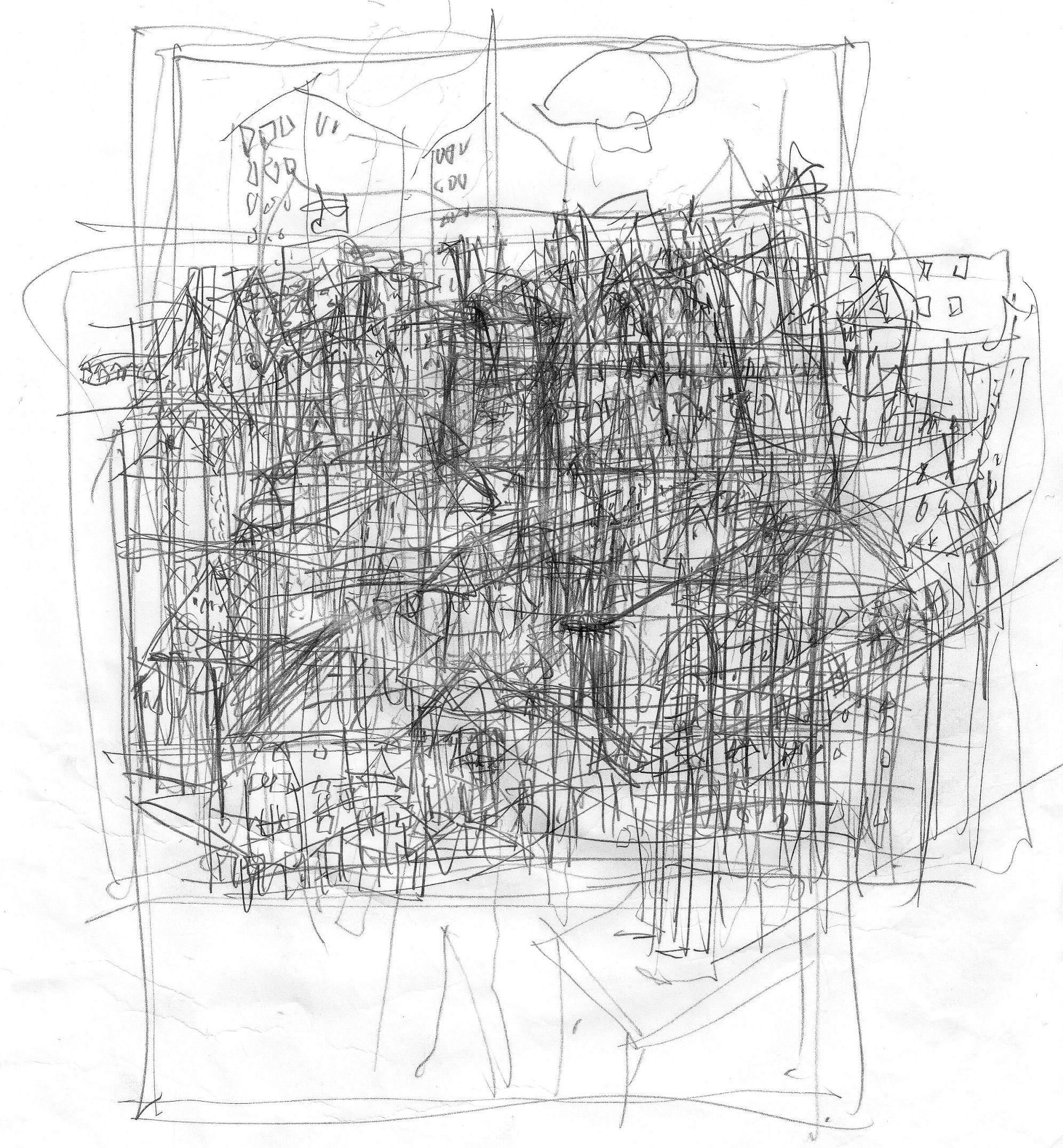

Prawigs $11-20$ of Rossis

Analuyeal (ity serie) 197679

centrid on the reget moutgen

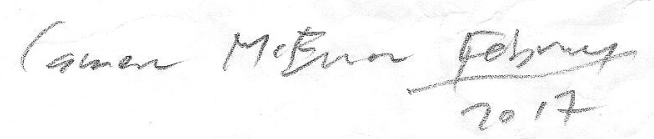

